\title{
MENGHILANGKAN BUDAYA MALU MENJADI PUSTAKAWAN
}

\author{
Oleh \\ I Ketut Artana, I Putu Putrayana Wardana \\ (Pustakawan Ahli Madya/Bagasartana7@gmail.com), putra.yana@undiksha.ac.id
}

\begin{abstract}
Abstrak
Pustakawan merupakan profesi di bidang perpustakaan. Pejabat fungsional pustakawan masih beranggapan bahwa profesinya merupakan profesi alternatif bukan profesi pilihan, profesi yang tidak memiliki masa depan yang cerah. Pustakawan tidak merasa bangga dengan profesi yang disandangnya, bahkan cenderung merasa malu, minder serta menyembunyikan predikatnya sebagai pustakawan. Kondisi seperti ini dapat menghambat upaya pengembangan pengelolaan dan peningkatan pelayanan perpustakaan. Oleh karena itu, diperlukan upaya dari pustakawan itu sendiri dan berbagai pihak yang terkait agar pustakawan tidak merasa malu, minder sebagai pustakawan. Upaya itu antara lain membagun citra positif pada diri pustakawan, meningkatkan kompetensi pustakawan, dan peran Ikatan Putakawan Indonesia (IPI) untuk membina dan mengembangkan jati diri pustakawan melalui berbagai program kerjanya. Melalui upaya-upaya tersebut, pustakawan pada akhirnya tidak merasa malu menjadi pustakawan. Ke depan, seorang pustakawan akan merasa bangga menyebut dirinya seorang pustakawan.
\end{abstract}

Kata kunci : budaya malu, pustakawan, upaya menghilangkan

\section{Pendahuluan}

Pustakawan sebagai sebuah profesi belum sepenuhnya diketahui oleh sebagian besar masyarakat Indonesia. Gambaran atau persepsi masyarakat terhadap profesi pustakawan masih dipertanyakan atau belum diterima sepenuhnya. Masyarakat menilai bahwa profesi pustakawan tanpa memiliki prospek yang jelas, hanya sebagai pejaga buku-buku (books keeper). Sementara, di kalangan petugas perpustakaan masih banyak beranggapan bahwa profesi pustakawan masih merupakan profesi alternatif, bukan profesi pilihan. Profesi pustakawan dianggap tidak memiliki masa depan yang cerah. Pustakawan tidak merasa bangga dengan profesi yang disandangnya, bahkan cenderung merasa malu, minder serta menyembunyikan predikatnya sebagai pustakawan.

Dalam upaya peningkatan pengelolaan perpustakaan khususnya pada pelayanan jasa informasi tentunya paradigma kepustakawanan seperti itu harus secepatnya dihilangkan. Pustakawan tidak akan dapat melaksanakan tugas dan fungsinya secara profesional apabila pustakawan sendiri tidak merasa bangga, merasa senang dengan profesi dan pekerjaannya. Dalam konteks ini tentunya harus ada upaya yang sungguh- 
sungguh untuk menghilangkan budaya malu menjadi pustakawan dan meningkatkan citra diri pustakawan dari berbagai aspek.

Berdasar pada hal-hal tersebut, berikut ini akan dikaji dan dibahas lebih mendalam terkait dengan rasa malu menjadi pustakawan, membangun citra diri pustakawan, kompetensi pustakawan dan peran Ikatan Pustakawan Indonesia (IPI) dalam peningkatan kepercayaan diri menjadi pustakawan.

\section{Malu Menjadi Pustakawan}

Profesi pustakawan telah diakui oleh pemerintah sebagai pejabat fungsional pustakawan berdasarkan Surat Keputusan Menpan No.18 Tahun 1988 dan disempurnakan terakhir dengan Keputusan Menpan No. 9 Tahun 2014, tentang Jabatan Fungsional Pustakawan dan Angka Kreditnya. Sebenarnya, banyak keuntungan yang didapat bilamana menjadi pustakawan, yaitu selain mendapat tunjangan fungsional, juga adanya perpanjangan masa pensiun bagi pejabat pustakawan, kenaikan pangkat dan jabatan menggunakan angka kredit, dapat mengikuti kegiatan ilmiah bidang perpustakaan, melakukan kegiatan pengkajian dan penelitian serta kegiatan lainnya yang mendukung tugas-tugas kepustakawanan. Walaupun begitu, di kalangan pustakawan sendiri masih banyak yang memiliki budaya malu atau minder menjadi pustakawan. Mengapa malu menyatakan diri secara terbuka sebagai pustakawan?

Bilamana dicermati dan dikaji secara saksama kondisi di lapangan, ada dua hal yang mendasari mengapa pustakawan malu atau minder menyebut dirinya sebagai pustakawan. Pertama, adalah pencitraan diri yang dibuat oleh pustakawan itu sendiri terhadap dirinya. Pustakawan merasa tidak punya prestise dengan profesinya, kurang percaya diri sebagai pustakawan, merasa sebagai 'tenaga buangan', predikat pustakawan tidak keren, merasa rendah diri, dan lain sebagainya. Kedua, bentukkan budaya stigma. Budaya yang menganggap bahwa pekerjaan pustakawan adalah pekerjaan yang tidak punya greget, monoton (bersifat rutinitas), membosankan dan melelahkan. Bahkan ada yang menyebut bahwa bekerja di perpustakaan tempatnya pegawai (karyawan) yang kurang berprestasi dan tempat yang 'kering' dari sisi kesejahteraan.

Kondisi seperti itu semestinya jangan dibiarkan berlarut-larut dan terbelenggu oleh pencitraan 'negatif' pada diri pustakawan. Dalam konteks ini perlu adanya terobosan baru dan upaya yang sungguh-sungguh pada diri pustakawan berupa kemauan yang kuat, tekad, motivasi untuk menghilangkan budaya malu menjadi pustawakan. Pustakawan sudah saatnya dan seharusnya membuka diri dan mau menyatakan "saya 
pustakawan". Untuk mewujudkan hal itu tentunya diperlukan adanya perbaikan citra diri pustakawan. Perbaikan citra diri pustakawan tidak bisa dilakukan sekaligus dalam waktu yang relatif singkat, akan tetapi dapat dilakukan melalui berbagai upaya untuk membangun citra diri positif guna menuju pustakawan yang berkualitas dan profesional.

\section{Membagun Citra Diri Pustakawan}

Secara sederhana citra diri dapat diartikan sebagai gambaran kita terhadap diri sendiri dan pikiran kita tentang pandangan orang lain terhadap diri kita. Dengan kata lain, apa yang dipahami orang lain tentang diri kita sebenarnya dibentuk oleh akumulasi sikap, perilaku, dan cara kita mengekspresikan diri. Kemunculan kita ke publik (masyarakat), dalam bentuk apapun, melalui suatu proses waktu. Secara perlahan-lahan akan membentuk kesan adan imej tertentu dalam benak publik. Apa yang mereka lihat, apa yang mereka dengar tentang kita, itulah yang menjadi faktor pembentuk citra diri kita dibenak mereka. Jadi, citra adalah kesan imajinatif yang terbentuk dalam benak publik dalam rentang waktu tertentu dan terbentuk oleh keselurahan informasi tentang diri kita yang sampai ke publik.

Persoalan kita adalah bagaimana melalukan upaya yang sistematis dan berkelanjutan untuk membentuk citra diri positif yang kita inginkan. Dalam konteks ini tentu saja yang perlu ditekankan adalah pustakawan harus dicitrakan sebagai sebuah profesi yang memiliki kelayakan untuk sejajar dengan profesi-profesi yang lain, seperti profesi dokter, jaksa, pendidik, dan yang lainnya. Bahkan, citra itu perlu dibangun untuk merebut kepercayaan masyarakat bahwa profesi pustakawan mempunyai peran utama dan penting di era informasi ini sebagai mitra kerja bagi profesi-profesi yang lain.

Selain itu, pustakawan itu sendiri harus menyadari akan arti pentingnya profesi dan mengoptimalisasi seluruh potensi yang dimiliki dan bisa membangun citra dirinya. Dengan begitu, pustakawan akan menjadi profesi yang mulia dan menjadi profesi yang memiliki prestise bagus di masa mendatang. Jadi, profesi pustakawan bukan sesuatu yang perlu disembunyikan dan disesali.

Dalam upaya mewujudkan citra diri positif pustakawan tentu saja semua elemen yang ada pada institusi kepustakawanan harus diekspos secara sistematis kepada publik sehingga publik mendapatkan gambaran secara utuh tentang seluruh kapasitas internal yang dimiliki oleh seorang pustakawan. Misalnya, dalam pemunculan publik figure kita. Kita harus memunculkan pustakawan yang 'layak diekspos' untuk menjadi duta baca, jadi tidak mengandalkan pada popularitas artis. Publik harus mendapatkan informasi 
bahwa intitusi kepustakawanan juga memiliki segudang tokoh dan pakar bidang pengelola sumber-sumber informasi (pustakawan) dan pengelola subjek informasi (spesialis informasi) dalam berbagai bidang pengetahuan. Pustakawan yang dimunculkan juga adalah orang-orang yang memiliki keahlian khusus, sehingga figure yang dimunculkan harus merata di semua bidang. Apakah itu pustakawan yang tokoh agama, pustakawan yang seni budaya (budayawan), pustakawan sosial kemasyarakatan, pustakawan politik, ekonomi, keamanan, pendidikan, ilmu pengetahuan dan bisnis, baik dalam kapasitas sebagai praktisi maupun pengamat.

Membangun citra diri positif pustakawan dapat dilakukan dengan cara meningkatkan kualitas pendidikan, pengetahuan, keterampilan, keahlian, performance (penampilan) dan tentu saja yang paling penting adalah peningkatan kesejahteraannya. Pustakawan jangan hanya dianggap sebagai penunggu buku-buku dan pelayan saja, akan tetapi harus dianggap (diakui) sebagai mitra kerja yang saling dibutuhkan dan dihargai. Jadi, kedudukannya antara pemustaka dan pustakawan adalah sama, sejajar dan seimbang bukan lagi hubungan antara pemustaka dan pelayan, melainkan hubungan mitra kerja yang bisa saling membantu untuk memenuhi kebutuhan pemustaka.

\section{Kompetensi Pustakawan}

Kompetensi adalah total dari kemampuan dan daya dukung yang secara riil kita miliki. Dengan begitu kita dapat merealisasikan kehendak atau ide-ide kita. Dalam kehidupan sehari-hari, orang-orang menilai kita berdasarkan apa yang kita inginkan atau berdasarkan ide-ide kita. Mereka menilai kita berdasarkan apa yang dapat kita lakukan atau berdasarkan kemampuan bertindak (daya tindak) kita. Dengan kata lain, mereka tidak akan pernah menanyakan visi, misi kita. Akan tetapi, mereka akan menanyakan seberapa mampu kita merealisasikan apa yang kita inginkan. Itulah logika masyarakat kita. Hal itu yang menjadi elemen utama yang membentuk kepercayaan orang kepada kita. Dalam konteks ini diperlukan upaya untuk membangun kepakaran kita.

Kompetensi kepakaran kita dibentuk oleh dua hal, yakni hard skill dan soft skill. Hard skill lebih bersifat scientific achievement; yang berkenaan dengan penguasaan teknis dan detail bidang kepustakawanan dan perpustakaan, sedangkan soft skill bersifat psychological achievement; berkaitan dengan kemampuan berpikir strategis sebagai perumus kebijakan, wawasan masa depan, dan kemampuan perencanaan strategis, kemampuan manajerial, kemampuan komunikasi publik, dan lainnya. 
Bersamaan dengan berkembangnya kompetensi melalui pengembangan kapasitas internal secara berkesinambungan, maka kinerja pustakawan akan meningkat. Dengan upaya ini pula kita dapat merebut kepercayaan publik bahwa pustakawan memang memiliki kelayakan untuk dihormati dan dihargai publik. Masyarakat punya alasan yang layak untuk 'berharap banyak' pada pustakawan. Tetapi, pembahasan tentang kompetensi ini tentu saja tidak menafikan integritas kepribadian yang berbasis pada kekuatan moralitas.

Untuk itu pustakawan harus mampu melakukan beberapa hal berkaitan dengan membangun kompetensi. Pertama, memperluas wawasan makro tentang persoalan bangsa. Hal itu dapat dilakukan dengan memperluas pengetahuan pustakawan dalam berbagai bidang ilmu, baik melalui sumber sekunder seperti media massa maupun sumber sekunder, yaitu para pelaku langsung. Hal ini mengharuskan pustakawan membaca bahan pustaka lebih banyak dan bergaul lebih luas.

Kedua, yaitu meningkatkan frekuensi keterlibatan pustakawan dalam dunia pendidikan, literasi informasi dan sosial. Pustakawan harus terlibat dalam agenda-agenda besar nasional, mulai dari wacana sampai pada tataran aksi. Contoh tentang kemiskinan, buta aksara, minat baca dan lain-lain.Keterlibatan itu dapat dilakukan di tingkat wacana publik, asistensi kepada pemerintah untuk pengambilan keputusan atau perumusan kebijakan publik, maupun terlibat sebagai pelaku langsung.

Ketiga, meningkatkan kemampuan dan keahlian untuk dapat mempengaruhi orang lain. Dalam era saat ini adalah dunia sistem jaringan, dunia kerjasama, dunia aliansi dan koalisasi. Janganlah pernah membayangkan bahwa pustakawan akan dapat berkembang dan bertahan sendirian. Jadi, apa yang harus pustakawan lakukan adalah mengembangkan kemampuan dan keahlian untuk mempengaruhi orang lain, memperkuat jaringan melalui lobi ke berbagai kalangan dan membangun akses yang kuat ke para pengambil keputusan dan penentu kebijakan.

Keempat, memperbanyak publik pigur pustakawan dalam berbagai bidang, seperti bidang ekonomi, politik, ataupun teknologi informasi yang dimunculkan. Artinya, harus ada spesialisasi di kalangan pustakawan. Pustakawan yang punya kemampuan intelektual lebih besar dapat diplot menjadi generalis yang terlibat secara ilmiah dalam banyak bidang pengetahuan. Akan tetapi tentu saja sebagian besar pustakawan harus punya satu spesialisasi. Dengan demikian pustakawan kemudian dapat dikenal oleh masyarakat. 


\section{Peran IPI ( Ikatan Pustakawan Indonesia)}

Peningkatan kualitas pustakawan dalam upaya membangun citra positif pustakawan sangat penting dilakukan oleh Ikatan Pustakawan Indonesia (IPI) sebagai organisasi profesi yang bertugas mengembangkan karir para pustakawan. Oleh karena itu peran penting IPI sangat diharapkan guna mampu memperbaiki citra 'negatif' pustakawan. Adapun peran yang kiranya dapat dimainkan oleh IPI berkaitan dengan peningkatan kualitas pustakawan, yaitu sebagai berikut.

1) IPI sebaikanya rajin mengusahakan (mencari donator) untuk biaya beasiswa bagi para pustakawan yang berpotensi melanjutkan studi $(\mathrm{S} 1, \mathrm{~S} 2)$ bidang perpustakaan dan informasi

2) IPI sebaiknya berusaha terus sampai berhasil memperjuangkan ke pihak pemerintah adanya peningkatan tunjangan fungsional pustakawan dan tunjangan insentif lainnya

3) Kode etik pustakawan hendaknya dilengkapi dengan aspek kepribadian dan perilaku yang wajib dihayati dan dipahami pustakawan agar dimuat atau dimasukan dalam setiap kurikulum diklat pustakawan

4) IPI sebaiknya menyediakan sarana atau media untuk publikasi ilmiah perpustakaan dan pustakawan

\section{Penutup}

Profesi pustakawan adalah profesi yang dipandang sebelah mata oleh sebagian besar masyarakat kita. Banyak pustakawan merasa malu atau minder mengakui dirinya sebagai pustakawan. Kondisi ini disebabkan oleh pencitraan diri yang dibuat oleh pustakawan itu sendiri terhadap dirinya dan adanya bentukan budaya stigma yang mengannggap bahwa pekerjaan pustakawan tidak punya greget, monoton dan membosankan.

Dalam upya menghilangkan budaya malu menjadi pustakawan sangat penting adanya suatu keinginan dan kemauan yang kuat dalam diri pustakawan untuk membangun citra diri yang positif dan membangun kompetensi yang bersifat hard skill dan soft skill serta adanya peran IPI untuk meningkatkan citra diri pustakawan. Melalui upaya tersebut citra pustakawan akan cemerlang dalam peradaban manusia, mensejajarkan diri dengan profesi yang lain sehingga pada akhirnya akan menyaksikan sebuah jaman dimana orang saling berebut untuk menjadi pustakawan. Dan profesi 
pustakawan tidak lagi akan menyaksikan atau mendengar pustakawan malu atau minder menjadi pustakawan. Semoga!

$* * * * * * * * *$

\section{Referensi}

Indonesia. (2014). Jabatan Fungsional Pustakawan dan Angka Kreditnya. Jakarta: Perpustakaan Nasional RI

Rompas, J.P. (2001). "Peran Pustakawan di Masa Mendatang" dalam seminar sambung rasa. Jakarta: Klub Pustakawan Indonesia

Tjitropramoto, Prabowo dan Tisyo Haryono. (1995). "Upaya Meningkatkan Kualitas Pustakawan", makalah pada Kongres IPI ke-7 dan Seminar Ilmiah Nasional IPI di Jakarta 